\title{
THE INFLUENCE OF SOCIAL MEDIA ADVERTISING ON PURCHASE BEHAVIOUR TOWARDS FAST-MOVING CONSUMER GOODS: A LITERATURE REVIEW
}

\author{
T.C. Chen \\ Department of Marketing, Strategy \& \\ Innovation \\ Bournemouth University \\ Dorset, United Kingdom \\ s5401413@bournemouth.ac.uk
}

\begin{abstract}
Traditional advertising is the main media employed by marketers in the FMCG sector to affect consumers decisions. However, people are exposed to plenty of advertising media from various forms and different channels every day, especially from social media. Therefore, digital advertising should be more powerful than traditional advertising in this era. This paper seeks to study when consumers choose daily necessities, whether these advertisements affect their decisions, and whether social media advertising effectively influences consumers purchase decisions. In order to promote the development of digital and social media advertising research in the FMCG sector, this paper proposes further research directions.
\end{abstract}

Keywords-traditional advertising, digital advertising, social media, purchase behaviour, FMCG

I.

INTRODUCTION

Fast-moving consumer goods (FMCG) refer to nondurable goods that are quickly sold at a relatively low cost, with low-profit margins but accounting for more than half of all consumer expenditures, which are the largest category of consumer goods market [1]. The FMCG includes food and non-food daily consumer goods, such as tobacco, cosmetics, toiletries and household items, these products are common in supermarkets and grocery stores [2]. These products are consumed rapidly and have a short shelf life. From a business perspective, the sales volume of FMCG is significantly huge, which is why there are so many FMCG brands, leading to fierce market competition [3]. In order to attract consumers to buy their brands, FMCG marketers need to implement effective marketing strategies, and advertising is one of the most commonly used and powerful marketing tools for marketers to convey brand information to their potential customers [4], [5], [6].

Advertising is one of the main modes of the marketing communications mix [5]. It can be divided into two main categories, traditional media and digital media. In the book of Kotler and Keller [5] highlights that traditional advertising indicates broadcast media (TV and radio), outdoor media (billboards, poster and bus Ads, etc.), print media (newspaper and magazine) and point of purchase. Digital advertising includes online media such as display ads on websites, landing pages, eNewletter, email marketing, search engine marketing and so on, and social media (Facebook, Instagram, Twitter, Snapchat and Tiktok).

\section{A. Effectiveness of Traditional Advertising in the FMCG Sector}

In the past decades, traditional advertising has been the major advertising tool adopted by many FMCG brands. Generally, TV advertising is considered the most powerful advertising medium because each exposure can reach a wide range of consumers. It is able to present product attributes visually and explain their corresponding consumer benefits convincingly [2], [5], [7]. In addition, television enables customers in rural areas to learn about products available on the market, and hence it plays a vital role in the FMCG segment [8].

Print advertising and outdoor advertising are also common tools employed by FMCG marketers. Outdoor advertising is used to evoke consumers' memories of brand awareness and brand image, and creative outdoor advertising can also give consumers a strong brand association [9]. Print advertising is usually in the form of magazines, newspapers and flyers, which can effectively provide consumers with detailed product information and promotion offers by visual image and text [5], [10]. A study by Sorce and Dewitz [11] found that magazine advertising is even more effective than TV advertising.

Point of purchase is the advertising that appears in the store which can be in many different forms, such as advertisements on shopping carts, ceilings and shelves, which is common to see in supermarkets [12]. The appeal of the point of purchase advertising lies in the fact that in many product categories, customers make most of the final brand decisions in the store [5]. Therefore, it helps FMCG brands to promote their products to transmit their brand information and promotional offers at the last minute, thereby trying to influence the final decision of consumers.

\section{B. Traditional Advertising VS Digital Advertising}

There are some studies [11], [13], [14] that argue traditional advertising plays a key role in affecting consumers purchase behaviours. TV advertising can consider as the best media since it has a major impact on improving brand awareness and brand recall [15]. Furthermore, Kakkad [16] states that even if newspapers can target specific groups, TV advertisements are more influential than newspaper advertisements. However, print advertising is still valued by marketers, for instance, a study found that magazine advertising is more effective than TV advertising for certain target groups [11]. It can be seen that traditional advertising is the most powerful tool for marketers to promote brands, especially in the FMCG 
sector. However, in this era where everything can be done online, digital advertising should be more effective than traditional advertising. In addition, the influence of social media on our daily lives is increasing [17], so it is crucial for researchers to understand whether social media advertising can have an impact that affects consumer purchase decisions.

Hence, this paper aims to investigate does social media advertising effectively influence consumers' purchase decisions on FMCG products? Can it play a key role in the FMCG sector?

To answer research questions, this paper conducts a literature review covering research in different disciplines. The structure of this paper is as follows: First, we are going to discuss the impacts of digital advertising. Second, providing an overview of existing research on social media in the FMCG sector. Finally, summarise the conclusions, and propose directions for further research to promote digital and social media advertising towards FMCG research forward.

\section{LITERATURE REVIEW}

\section{A. Impacts of Digital Advertising}

With the widespread of smartphones, the internet has provided the advertising industry with more rich media tools and global influence, it enables marketers to use digital media to disseminate brand information interactively at a lower cost [18]. As the role of traditional media is gradually weakened, this has led to a significant increase in the popularity of digital advertising [19]. By investing advertising in digital media, marketers can formulate marketing strategies for a wider range of regions and more target audiences, and it is easier to measure results compared with traditional advertising [20]. As social media has become more and more popular in this decade, it enables consumers to participate in brands more deeply and widely than ever before. Social media has become a strategic tool for rapid development, marketers consider social media as their important advertising channel since it allows them to create personalized messages to target audiences and receive feedback effectively [6].

Some studies [20], [21] show that digital and social media empower consumers, and brands play a significant role in promoting dialogue between consumers and themselves. Through interacting with customers, helps brands to establish contact with customers, thereby promoting consumers generate strong brand engagement and increasing brand associations [22]. Furthermore, research by Sama [23] shows that traditional advertising is effective to remain high brand recall but digital advertising has a greater impact on pre-purchase and post-purchase behaviours that affect consumers. Pre-purchase is where consumers conduct product research before making buying decisions, and post-purchase is a significant stage for brands [23]. It depends on whether the positive experience is generated by consumers after consuming the products, which is the key step in building brand loyalty, thereby increasing repeat purchases [24].

\section{B. Social Media Advertising Towards FMCG Products}

Significant changes have taken place in offline marketing, and the importance of online marketing communication forms and online marketing platforms is increasing [25]. With the widespread popularity of the internet and social media, even rural residents now use social media as a daily communication tool [26]. Nowadays, social media is an important tool for consumers to search for product information, and it can influence their purchasing decisions [27], [28]. The study of Banerjee [29] shows that FMCG marketers through social media advertising succeed in producing attention and recall value to consumers than traditional advertising. Social media advertising enables FMCG marketers to transmit the brand messages to designated audiences based on target segments and preferences, this can ensure that target groups have access to brand information, thereby influencing their purchasing decisions. A recent study [30] shows that brands make use of a wide range of social media advertising to provide massive product information to consumers, which make them receive the brand information successfully, and generate brand association with brands and make purchase decisions. As consumers are exposed to a huge number of social media advertisements, it may succeed to enhance their memories of brands and product information, thereby affecting them to buy the products. Haddad [27] highlights that social media can be regarded as an influential tool for marketing communication strategies because it provides an excellent opportunity to communicate with consumers. In the study of Banerjee [29] found that from the consumers perspective, they believe that social media provide them with a high degree of freedom to interact with the brand and more opportunities to give opinions to the brand, which is unmatched by traditional media. It is worth noticing that the research findings show that many consumers believe that they purchase products of the designated FMCG brand because they have obtained brand information from social media platforms that impresses them. This shows that FMCG marketers can successfully convey their product information to targeted consumers through social media advertising, they need to develop social media advertising strategies for specific groups to ensure they receive the product information.

In terms of the effectiveness of social media advertising for FMCG products, it may vary based on demographics and geography [28], [31]. A study [32] argues that social media can be one of the effective methods to attract Generation $\mathrm{Y}$ consumers and encourage them to make purchase decisions. Social media has become an indispensable part of their lives and they tend to follow these types of advertisements [31], [33]. Some studies [28], [30] underline that these age groups are easily stimulated by social media and especially young men under 30 . Therefore, successful social media advertising can attract them, thereby stimulating their interest in the product, and perform more deep information research and make purchase decisions [32]. Regarding geography, some studies [28], [31] argue that the effectiveness of social media advertising may vary in different countries, especially emerging countries. However, social media advertising is increasingly prominent in emerging countries and its effectiveness cannot be completely denied. Social media advertising still has a certain impact on the FMCG market in emerging countries [28]. A recent study [34] highlights that different forms of social media advertisements have significant impacts on interaction and engagement, which means that using effective strategies can make social media advertising become an effective communication tool for brands to promote their products in emerging countries.

III.

\section{CONCLUSIONS}

Social media is a decisive communication tool for marketers to interact with consumers and provide them with product information [20], [27], [28], [29], [30]. Day after day exposure in the massive FMCG advertisements on social media platforms can bring a deep impression for consumers, thereby triggering them to perform purchase decisions [29], [30]. FMCG brands can interact with consumers via social media, which helps increase customers 
brand engagement, which is also an effective way to stimulate them to purchase products [29]. Furthermore, social media advertising is effective for generation $\mathrm{Y}$ [32], [33]. These people are the main consumer group and the main group who buy FMCG products. Hence, FMCG marketers can use strategic advertising to affect their purchase decision. Although the effectiveness of social media advertising may vary in different countries, it still has a certain impact affect consumer decisions [28]. Its effect can be improved by using strategies, such as frequency of posts and using more videos [34].

In addition, many studies [20], [23], [28], [29], [31] underline that social media is an effective tool for marketing communications, however, these studies argue that traditional media still plays a significant role in advertising. Since social media is a more personalized tool compared to traditional media which is more suitable for delivering personalised information [29], [30]. Although social media plays an important role in influencing pre-purchase and post-purchase behaviour [23], it is far from becoming a key role in the FMCG sector, but a supporting role. Traditional media has gained stronger insights than social media [29]. Moreover, traditional media such as TV advertisement is the major marketing communication tool employed by FMCG marketers, especially in emerging countries [28], [29]. Many marketers believe that TV advertisements can bring huge sales to brands [2], [14]. Since FMCG is mainly household products, a great number of households can be reached through TV advertising [14]. In conclusion, social media advertising can effectively influence consumers' purchase behaviour but it does not play a key role in the FMCG sector. However, social media advertising has developed rapidly and has great potential. As a marketing communication tool, its role in the FMCG industry may undergo a significant change in the future.

\section{SCOPE OF FURTHER RESEARCH}

It is worth noting that there are many studies that focus on analysing geography and demographics, user behaviour, the length of time using social media and types of social media platforms while neglecting the measurement of social media advertising forms. Social media advertising can be in different forms, such as opinions from influencers, word-ofmouth reviews, sponsored posts, videos and so on. Since different forms of social media advertising may have different impacts, it is recommended to further study comparing forms of social media advertising and which form is the most effective, as well as measuring the effectiveness of digital and social media advertising compared with traditional media marketing.

$\mathrm{V}$.

\section{LIMITATIONS}

Most papers only analyse the effectiveness of traditional media in the FMCG sector and neglect the comparison with digital and social media advertising. Moreover, there are few types of research on digital advertising, and hence comparable papers are finite.

\section{REFERENCES}

1. Y. Durmaz, "The Impact of Psychological Factors on Consumer Buying Behavior and an Empirical Application in Turkey," Asian Social Science, vol. 10, no. 6, Feb. 2014, doi: 10.5539/ass.v10n6p194.

2. G. Patra, C. K. Dash, and R. Patnaik, "Television Advertisement and its Impact on Teenagers' Buying Behavior-A Study in Barasat City Kolkata," Parikalpana: KIIT Journal of Management, vol. 13, no. 2, p. 58, Dec. 2017, doi: 10.23862/kiit-parikalpana/2017/v13/i2/164521.

3. G. Prakash and P. Pathak, "Understanding Rural Buying Behaviour: A Study with Special Reference to FMCG Products," Indian Journal of Marketing, vol. 44, no. 8, p. 43, Aug. 2014, doi: 10.17010/ijom/2014/ v44/i8/80132.
4. L. Bogart, Strategy in advertising: matching media and messages to markets and motivations. Lincolnwood, Il: Ntc Business Books, 1996.

5. P. Kotler and K. L. Keller, Marketing Management, 15th ed. Boston: Pearson, 2016.

6. L. G. Schiffman and J. Wisenblit, Consumer behavior, 12th ed. Upper Saddle River, New Jersey Pearson Education, 2019.

7. T. V. Chithra and S. Kothai, "Television Viewing Behaviour of Consumers and Television Advertisements' Impact on Consumers' Purchase Decision," CLEAR International Journal of Research in Commerce \& Management, vol. 6, no. 10, pp. 75-79, 2015.

8. K. Asha and A. Merlin Thanga Joy, "Attitudinal Analysis of Rural Consumers towards FMCG Products in Sivagangai District," Indian Journal of Science and Technology, vol. 9, no. 33, pp. 1-5, 2016, doi: 10.17485/ijst/2016/v9i33/98461.

9. R. T. Wilson, D. W. Baack, and B. D. Till, "Creativity, attention and the memory for brands: an outdoor advertising field study," International Journal of Advertising, vol. 34, no. 2, pp. 232-261, Feb. 2015, doi: 10.1080/02650487.2014.996117.

10. C. Farai and N. Joram, "The Impact of the Print Media on Building a Destination Brand Equity in Zimbabwe," African Journal of Hospitality Tourism and Leisure, vol. 8, no. 3, pp. 1-18, 2019.

11. P. A. Sorce, A. Dewitz, and Rochester Institute Of Technology. Printing Industry Center, The case for print media advertising in the internet age. Rochester, NY: Printing Industry Center, Rit, 2007.

12. R. Wang, "Capability-oriented 'Point of Purchase Advertising' Teaching Reform Research," Proceedings of the 2013 Conference on Education Technology and Management Science (ICETMS 2013), Jun. 2013, doi: 10.2991/icetms.2013.232.

13. K. Pongiannan and J. Chinnasamy, "Do Advertisements for Fast Moving Consumer Goods Create Response among the Consumers? An Analytical Assessment with Reference to India," International Journal of Innovation, Management and Technology, 2014, doi: 10.7763/ijimt.2014.v5.522.

14. T. Vasumathi and P.B. Banudevi, "Impact of Television Advertisement On The Buying Behaviour of FMCG Customers In Coimbatore District: A Study," International Journal of Research in Applied Management, vol. III, no. II, 2018.

15. B. Anjum, A. Irum and N. Sualtan, "Impact of television advertisements on consumer buying behaviour: The moderating role of religiosity in the context of Pakistan," International Interdisciplinary Journal of Scholarly Research, vol. 1, no. 3, pp. 36$48,2015$.

16. R. Kakkad, "A study on effect of newspaper advertisement on consumer buying behavior of two wheelers," Philica, vol. II, no. II, p. $35,2016$.

17. S. Satpathy and S. Patnaik, "Role of Social Media Marketing on Consumer Purchase Behaviour: A Critical Analysis," 2019 International Conference on Applied Machine Learning (ICAML), 2019, doi: 10.1109/ICAML48257.2019.00026.

18. V. Venkatraman, A. Dimoka, K. Vo, and P. A. Pavlou, "Relative Effectiveness of Print and Digital Advertising: A Memory Perspective," SSRN Electronic Journal, 2018, doi: 10.2139/ ssrn.3254528.

19. P. J. Danaher and J. R. Rossiter, "Comparing perceptions of marketing communication channels," European Journal of Marketing, vol. 45, no. 1/2, p p. 6-42, Feb. 2011 , doi: 10.1108/03090561111095586.

20. P. Deshwal, "Online advertising and its impact on consumer behavior," International Journal of Applied Research 2016, vol. 2, no. 2, pp. 200-204, 2016.

21. T. Powers, D. Advincula, M. S. Austin, S. Graiko, and J. Snyder, "Digital and Social Media In the Purchase Decision Process," Journal of Advertising Research, vol. 52, no. 4, pp. 479-489, Dec. 2012, doi: 10.2501/jar-52-4-479-489.

22. H. Chahal, J. Wirtz, and A. Verma, "Social media brand engagement: dimensions, drivers and consequences," Journal of Consumer Marketing, vol. ahead-of-print, no. ahead-of-print, Dec. 2019, doi: 10.1108/jcm-11-2018-2937.

23. R. Sama, "Impact of Media Advertisements on Consumer Behaviour," Journal of Creative Communications, vol. 14, no. 1, pp. 54-68, Feb. 2019, doi: 10.1177/0973258618822624.

24. R. L. Oliver, Satisfaction: a behavioral perspective on the consumer. Armonk, N.Y. M.E. Sharpe, 2010.

25. A. Adhikari, Strategic marketing issues in emerging markets. Singapore: Springer, 2018.

26. S. Uddin, S. Chowdbury and M. Mamun, "Problems and Prospects of Brand Communication through Social Media: Evidence in 
Bangladesh," Global Journal of Management And Business Research, vol. 17, no. 1, pp. 1-9, 2017.

27. M. Haddad, 21st Century Fmcg Consumer Marketing: Creating Customer Value by Putting Consumers at the Heart of FMCG Marketing Strategy. Morrisville: Lulu Publishing Services, 2016.

28. J. Bednarz and P. Orelly, "The importance of social media on the FMCG market in Bangladesh," International Journal of Management and Economics, vol. 56, no. 3, pp. 230-242, Sep. 2020, doi: 10.2478/ ijme-2020-0019.

29. B. Banerjee, "Traditional Vs. Social Media As A Marketing Communications Tool In Fmcg Sector In India," Asia Pacific Journal of Research, vol. I, no. XXI, pp. 154-162, 2015.

30. S. Amin, A. G. Dunn, and L. Laranjo, "Exposure to e-cigarette information and advertising in social media and e-cigarette use in Australia: A mixed methods study," Drug and Alcohol Dependence, vol. 213 , p. 108112 , Aug. 2020 , doi: 10.1016/ j.drugalcdep.2020.108112.

31. R. Vidhya and K. Kalaiselv, "A Study on the Influence of Social Media in Digital marketing on Purchase intention of To FMCG Products," Turkish Journal of Computer and Mathematics Education, vol. 12, no. 10, pp. 7094-7100, 2021, doi: 10.17762/ turcomat.v12i10.5600.

32. V. Davidaviciene, I. Meidute-Kavaliauskiene, and R. Paliulis, "Research on the Influence of Social Media on Generation Y Consumer Purchase Decisions," Marketing and Management of Innovations, no. 4, pp. 39-49, 2019, doi: 10.21272/mmi.2019.4-04.

33. M. J. Tang and E.T. Chan, "The Impact of Online Advertising on Generation Y's Purchase Decision in Malaysia," International Journal of Humanities and Social Sciences, vol. 11, no. 4, pp. 973981, Apr. 2017, doi: 10.5281/zenodo.1130451.

34. G. Aydin, N. Uray, and G. Silahtaroglu, "How to Engage Consumers through Effective Social Media Use-Guidelines for Consumer Goods Companies from an Emerging Market," Journal of Theoretical and Applied Electronic Commerce Research, vol. 16, no. 4, pp. 768790, Jan. 2021, doi: 10.3390/jtaer16040044. 